\title{
Konflik Antar Nilai bagi Suksesi Perubahan Kebijakan dalam Pengembangan Organisasi
}

\author{
Fajar Apriani
}

Program Studi Ilmu Administrasi Negara, Fakultas Ilmu Sosial dan Ilmu Politik, Universitas Mulawarman, Indonesia. E-mail: yaniefajar@yahoo.com

\section{ARTICLE INFO}

\section{Keywords: Value, conflict, policy succession, policy changes, organization development}

Kata kunci: Nilai, konflik. suksesi kebijakan, perubahan kebijakan, pengembangan organisasi

\section{How to cite:} Apriani, F. (2019) Konflik Antar Nilai bagi Suksesi Perubahan Kebijakan dalam Pengembangan Organisasi. JAKPP (Jurnal Analisis Kebijakan dan Pelayanan Publik), 5(1), 62-79.

\begin{abstract}
Besides the allocation of various resources, the allocation of values to manage various interests through public policy is the background of the emergence of conflict. The high potential of conflict requires the presence of a policy maker who can be in a neutral position. But in the reality of organizational life, the resulting public policy often triggers conflict itself. The cause of conflict is the variation and conflict of values or interests held by each actor. In general, such conditions are further exacerbated by the way public policy is managed which tends to ignore values and value conflicts as well as elitist-technocratic managed policy processes that limit or minimize the space of reasoning between interest actors. This condition becomes an obstacle in policy succession as part of policy changes for organizational development. Then a leader of an organization must be able to identify the orientation dimensions of conflict handling and be aware of the right conditions or situations to do so because understanding and decision making regarding appropriate conflict handling steps will be able to bring the organization to the use of functional conflicts for organizational development.
\end{abstract}

\begin{abstract}
Abstrak
Disamping pengalokasian berbagai sumberdaya, pengalokasian nilai-nilai untuk mengelola berbagai kepentingan melalui kebijakan publik merupakan latar kemunculan konflik. Tingginya potensi konflik mengharuskan kehadiran seorang aktor pengambil kebijakan yang dapat berada pada posisi netral. Namun dalam realita kehidupan organisasi, kebijakan publik yang dihasilkan justru seringkali memicu konflik itu sendiri. Penyebab konflik adalah adanya variasi dan benturan nilai atau kepentingan yang dimiliki oleh setiap aktor. Umumnya, kondisi yang demikian semakin diperparah oleh cara kebijakan publik dikelola yang cenderung mengabaikan nilai dan konflik nilai serta proses kebijakan yang dikelola secara elitis-teknokratis yang membatasi atau meminimalkan ruang penalaran antar aktor kepentingan. Kondisi ini menjadi hambatan dalam suksesi kebijakan sebagai bagian dari perubahan kebijakan bagi perkembangan organisasi. Maka seorang pemimpin suatu organisasi harus mampu mengidentifikasi dimensi orientasi penanganan konflik dan menyadari kondisi atau situasi yang tepat untuk melakukannya sebab pemahaman dan pengambilan keputusan mengenai langkah penanganan konflik yang tepat akan mampu membawa organisasi pada pemanfaatan konflik yang fungsional bagi pengembangan organisasi.
\end{abstract}

Copyright @ 2019 JAKPP. All rights reserved.

\section{Pendahuluan}

Konflik merupakan sebuah keniscayaan dalam setiap kebijakan publik. Kebijakan publik sebagai instrumen politik untuk mengalokasikan nilai-nilai perlu diperlakukan sedemikian rupa oleh aktor pengambil kebijakan. Sebab sebagaimana 
dikatakan oleh Bromell (2012) bahwa kebijakan publik pada hakekatnya berurusan dengan bagaimana memutuskan "who gets what and who pays given relative resource scarcity". Namun kemudian muncullah pertanyaan nilai milik siapakah dan nilai yang manakah yang akan mendapatkan alokasi dari aktor pengambil kebijakan? Atau publik mana yang diwadahi nilainya dalam kebijakan publik?

Hingga kini, belum banyak kajian yang memberi perhatian pada sentralitas konflik dalam kebijakan publik. Tulisan ini berupaya menelaah keterkaitan pengalokasian nilai dalam kebijakan publik sebagai salah satu sumber konflik dengan mencermati substansi empiris dari kasus-kasus kebijakan penataan organisasi sektor publik, untuk memberikan pemahaman terhadap konflik dan peran sentral nilai dalam praktek kebijakan publik yang tidak hanya seringkali berfokus pada lingkungan birokrasi.

Mengutip definisi kebijakan publik yang dikemukakan oleh David Easton bahwa kebijakan publik merupakan instrumen politik untuk mengalokasi nilai, maka konsep kunci untuk memahami konsep kebijakan publik adalah "nilai", terutama "nilai publik" yang melekat pada kebijakan publik itu. Dalam perdebatan teoritis, konsep nilai seringkali dianggap kontroversial sebab para ahli kebijakan mengalami kesulitan untuk mengoperasionalkan dan menginstrumentasikannya dalam tataran yang lebih konkrit. Maka dari itu Taufiqurokhman (2016) menyatakan banyak ahli yang menghindari konsep nilai sebagai referensi dalam proses pembuatan kebijakan, apalagi konflik antar nilai dalam kebijakan publik (de Graaf dan van der Wal, 2010; van der Wal dkk, 2011).

Kebijakan publik beroperasi dalam sebuah arena yang memungkinkan adanya pluralitas dimensi, antara lain pluralitas aktor, kepentingan, nilai, kekuasaan, pengetahuan, informasi dan lain sebagainya. Setiap aktor memiliki kepentingan dan nilai yang berbeda yang tentu akan diperjuangkan untuk dapat diwujudkan dengan sesungguh-sungguhnya. Sehingga kebijakan publik di satu sisi memegang peran dalam hal pengalokasian sumberdaya untuk memenuhi kebutuhan atau nilai tertentu, namun di sisi lain dapat berkedudukan sebagai penyebab konflik jika memiliki ketidakmampuan dalam mengelola proses alokasi yang mampu memuaskan semua pihak (O'Kelly dan Dubnick, 2005; Spicer, 2009; Lele dalam Subarsono, 2016).

Pada prakteknya, banyak aktor justru menghindari konflik, bukan justru mengelola konflik itu melalui kebijakan publik. Atau bahkan, konflik justru berupaya dihilangkan karena dianggap menghambat suksesnya suatu kebijakan publik. Hal ini tentu berlandaskan pada pandangan tradisional terhadap konflik. Sudah saatnya, konflik dihadapi dengan pengelolaan yang tepat untuk dapat mengimplementasikan suatu perubahan di dalam organisasi sektor publik. Melalui tinjauan teoritis ini maka diharapkan konflik nilai yang terjadi di dalam suatu lingkungan organisasi sektor publik dapat dikelola secara tepat dalam rangka mensukseskan perubahan kebijakan yang dilakukan oleh pimpinan organisasi. 


\section{Tinjauan Pustaka}

Membangun kebijakan publik unggul tidak hanya menjadi pekerjaan rumah pemerintahan di negara berkembang, tetapi di seluruh dunia. Kebijakan publik dikatakan Nugroho (2018) seharusnya hadir untuk memberikan kehidupan publik yang hebat.

Kebijakan publik adalah masalah kemampuan negara untuk menggendong rakyatnya. Dari analogi tersebut dapat dipahami jika kapasitas gendong suatu negara sama dari tahun ke tahun, kebutuhan warganya harus ditekan agar terus tetap sama berada di bawah kapasitas tersebut. Artinya, tidak ada kemajuan bagi kehidupan bangsa tersebut. Namun jika kapasitas gendong suatu negara menurun, kebutuhan warga semakin ditekan, maka semakin miskinlah bangsa itu (Nugroho, 2018). Maka dapat disimpulkan bahwa setiap negara berkepentingan untuk meningkatkan kapasitas gendongnya dari waktu ke waktu agar dapat memberi ruang lebih besar bagi warganya unuk hidup lebih sejahtera. Kapasitas gendong tersebut bergantung pada adanya kebijakan negara sebagai daya pengungkitnya.

Untuk dapat memahami pengaruh nilai bagi suksesi sebuah kebijakan yang dapat berada pada posisi sebagai sumber konflik dalam perubahan kebijakan, diperlukan kajian teoritis terhadap teori konflik, teori kebijakan publik dan konsep masalah publik dan masalah kebijakan.

\section{Teori Konflik}

Teori konflik adalah teori yang memandang bahwa perubahan sosial tidak terjadi melalui proses penyesuaian nilai-nilai yang membawa perubahan, tetapi terjadi akibat adanya konflik yang menghasilkan kompromi-kompromi yang berbeda dengan kondisi semula (Raho, 2007).

Teori konflik merupakan antithesis dari teori struktural fungsional, dimana teori struktural fungsional sangat mengedepankan keteraturan dalam masyarakat. Sedangkan teori konflik melihat bahwa keteraturan tidak akan selamanya berada di dalam masyarakat. Masyarakat manapun pasti pernah mengalami konflik atau ketegangan-ketegangan dalam sistem sosial. Teori konflik juga melihat adanya dominasi, koersi, dan kekuasaan di dalam masyarakat, yang menghasilkan superordinasi dan subordinasi. Superordinasi dan subordinasi inilah yang dapat menimbulkan konflik karena adanya perbedaan kepentingan.

Namun teori konflik juga mengatakan bahwa konflik diperlukan agar tercipta suatu perubahan sosial. Ketika teori struktral fungsional mengatakan bahwa perubahan sosial dalam masyarakat selalu terjadi pada titik equilibrium, maka teori konflik justru melihat perubahan sosial terjadi akibat adanya konflik-konflik kepentingan. Namun diyakini bahwa pada suatu titik tertentu, masyarakat mampu mencapai sebuah kesepakatan bersama. Di dalam konflik, selalu ada negosiasinegosiasi yang dilakukan sehingga tercipta suatu konsensus. Sehingga keteraturan yang terjadi di masyarakat, sesungguhnya adalah akibat paksaan (koersi).

Maka konflik pada awalnya dianggap sebagai suatu penyimpangan terhadap nilai-nilai yang berlaku di masyarakat maupun organisasi, namun dengan meningkatnya pengetahuan maka pandangan terhadap konflik mengalami 
perubahan. Terdapat tiga macam mazhab pemikiran tentang konflik (Robbins, 1991) : 1) Pandangan Tradisional (terjadi pada masa 1930 hingga 1940-an), memandang konflik secara negatif dan seringkali dinyatakan bersinonim dengan kekerasan, destruktif, serta irasionalitas guna memperkuat konotasi negatifnya. Konflik dianggap merugikan dan perlu dihindari sehingga memberikan suatu pendekatan sederhana dengan memperhatikan perilaku orang-orang yang menciptakan konflik, 2) Pandangan Hubungan Antarmanusia (terjadi pada masa 1940 hingga 1970-an), menganggap konflik merupakan suatu kejadian alamiah yang dapat terjadi pada semua kelompok dan organisasi sehingga bersifat tidak dapat dihindari. Maka dianjurkan untuk menerima konflik sebagai suatu kewajaran dan merasionalisasikan eksistensi konflik. Konflik tidak dapat ditiadakan dan bahkan pada saat-saat tertentu konflik dianggap menguntungkan kinerja suatu kelompok kerja, 3) Pandangan Interaksionis, menganjurkan konflik berdasarkan alasan bahwa sebuah kelompok yang harmonis, penuh kedamaian, yang tenang, serta yang bekerjasama, cenderung berkembang menjadi kelompok yang statis, apatis dan tidak memberikan reaksi apapun terhadap kebutuhan akan perubahan dan inovasi. Menurut pandangan ini, para pemimpin kelompok perlu mempertahankan suatu tingkat konflik minimum yang berkelanjutan, yang cukup merangsang kelompok tersebut untuk bertahan, dapat mengkritik diri sendiri dan bersifat kreatif. Maka konflik dapat dipandang baik atau buruk tergantung dari tipe konflik yang muncul, yang perlu dibedakan apakah konflik itu fungsional atau disfungsional.

Coser (1965) mengemukakan sejumlah fungsi positif konflik bahwa konflik dapat merupakan proses yang bersifat instrumental dalam pembentukan, penyatuan dan pemeliharaan struktur sosial. Konflik dapat menempatkan dan menjaga garis batas antara dua atau lebih kelompok. Konflik dengan kelompok lain dapat memperkuat kembali identitas kelompok dan melindunginya agar tidak lebur ke dalam dunia sosial sekelilingnya.

Coser (1965) membagi konflik menjadi dua, yaitu:

1. Konflik Realistis, berasal dari kekecewaan terhadap tuntutan-tuntutan khusus yang terjadi dalam hubungan dan dari perkiraan kemungkinan keuntungan para partisipan, dan yang ditujukan pada objek yang dianggap mengecewakan.

2. Konflik Non-Realistis, konflik yang bukan berasal dari tujuan-tujuan saingan yang antagonis, tetapi muncul dari kebutuhan untuk meredakan ketegangan, paling tidak dari salah satu pihak. Contohnya masyarakat maju yang melakukan pengkambinghitaman sebagai pengganti ketidakmampuan melawan kelompok yang seharusnya menjadi lawan mereka.

Berkenaan dengan kedua jenis konflik tersebut, Coser (1965) menyatakan bahwa terdapat suatu kemungkinan bahwa seseorang terlibat dalam konflik realistis tanpa sikap permusuhan atau agresi. Akan tetapi apabila konflik berkembang dalam hubungan-hubungan yang intim, maka pemisahan (antara konflik realistis dan nonrealitis) akan lebih sulit untuk dipertahankan. Coser menyatakan bahwa semakin dekat suatu hubungan, semakin besar rasa kasih sayang yang sudah tertanam, sehingga semakin besar juga kecenderungan untuk menekan ketimbang mengungkapkan rasa permusuhan. Sedangkan pada hubungan-hubungan sekunder, seperti misalnya dengan rekan bisnis, rasa permusuhan dapat relatif bebas 
diungkapkan, dimana kondisi ini tidak selalu dapat terjadi di dalam hubunganhubungan primer yang memiliki keterlibatan total para partisipan (Poloma, 1994).

Peningkatan konflik kelompok juga dapat dihubungkan dengan peningkatan interaksi dengan masyarakat secara keseluruhan (Coser, 1967). Bila konflik dalam kelompok tidak ada, berarti hal ini menunjukkan lemahnya integrasi kelompok tersebut dengan masyarakat. Coser (1967) menyatakan bahwa perbedaan merupakan peristiwa normal yang sebenarnya dapat memperkuat struktur sosial.

Dengan demikian maka dapat dipahami bahwa perbedaan kepentingan akan memunculkan suatu kondisi superordinasi dan subordinasi yang bermuara pada timbulnya konflik karena adanya dominasi kekuasaan dan koersi di dalam suatu sistem sosial atau organisasi. Namun konflik yang muncul tersebut akan menciptakan suatu perubahan sosial dalam rangka pembentukan struktur sosial baru atau justru menjadi proses penyatuan dan pemeliharaan struktur sosial yang telah ada.

\section{Teori Kebijakan Publik}

Menurut Nugroho (2018) kebijakan publik adalah setiap keputusan yang dibuat oleh negara sebagai strategi untuk merealisasikan tujuan dari negara. Kebijakan publik adalah strategi untuk mengantar masyarakat pada masa awal, memasuki masyarakat pada masa transisi, untuk menuju kepada masayarakat yang dicitacitakan. Definisi tersebut menunjukkan bahwa kebijakan publik lebih kepada fakta strategis daripada fakta politis ataupun fakta teknis.

Sebagai sebuah strategi, maka di dalam kebijakan publik sudah terangkum preferensi-preferensi politis dari para aktor yang terlibat di dalam proses kebijakan, khususnya pada proses perumusan. Sebagai sebuah strategi, maka kebijakan publik tidak saja bersifat positif, namun juga negatif, di dalam arti pilihan keputusan selalu bersifat menerima salah satu dan menolak yang lain. Meskipun terdapat ruang bagi win-win dimana sebuah tuntutan dapat diakomodasi, namun pada akhirnya ruang bagi win-win sangat terbatas, sehingga kebijakan publik lebih banyak pada ranah zerosum-game, yaitu menerima yang ini, dan menolak yang lain. Dalam pemahaman ini, istilah "keputusan" termasuk juga ketika pemerintah memutuskan untuk "tidak memutuskan" atau memutuskan untuk "tidak mengurus" isu terkait (Nugroho, 2018).

Dye (1992) beranggapan bahwa kebijakan publik adalah untuk memperbaiki kehidupan masyarakat. Beberapa macam teori kebijakan publik:

1. System Theory: Kebijakan publik dianggap sebagai output dari sebuah sistem politik. Konsep mengenai sistem politik menyatakan bagaimana institusi-institusi dan aktivitasnya mampu merespon dan mentransformasikan kebutuhan yang ada dalam masyarakat untuk menjadi nilai yang mengikat masyarakat secara otoritatif dan memperoleh dukungan darinya. Teori sistem dipengaruhi oleh konsep dan teori dalam ilmu komunikasi seperti adanya feedback, input, output, serta percaya bahwa keseluruhan proses bersifat cyclical.

2. Elite Theory: Kebijakan publik dilihat sebagai preferensi dan nilai dari elit 
pemerintah. Meskipun sering kebijakan publik merefleksikan kebutuhan masyarakat, hal ini dapat terjadi melalui:

a. Kebijakan publik dibuat secara inkremental dan membawa nilai-nilai dari kepentingan para elit. Nilai-nilai dari para elit akan sangat mempengaruhi publik. Akan tetapi elitisme tidak berarti bahwa kebijakan publik anti terhadap kepentingan (kesejahteraan) masyarakat. Kebijakan publik yang ada merespon kesejahteraan masyarakat justru lebih mengutamakan kepentingan para elit daripada kepentingan masyarakat secara umum.

b. Para elit melihat sebagian besar masyarakat yang pasif, terjadi distorsi informasi, sentimen masyarakat dimanipulasi oleh para elit.

Maka dalam model ini diasumsikan bahwa masyarakat terbagi dalam dua kelompok besar, yaitu mereka yang memiliki kekuasaan dan yang tidak memiliki kekuasaan. Elit berkuasa karena mereka lebih pintar, lebih tahu masalah yang dihadapi masyarakat. Hingga kebijakan yang dibuat bersifat topdown. Dengan demikian dapat dipahami bahwa model ini hanya efektif dalam lingkungan dimana masayarakat bersikap pasif serta terjadi distorsi informasi.

3. Group Theory: Kebijakan sebagai ekuilibrium kelompok. Adalah hasil perjuangan dari kelompok yang berjuang sebagai keseimbangan individu di dalam politik yang tidak akan berarti kalau tidak mengatasnamakan kepentingan kelompok. Kebijakan publik adalah ekuilibrium yang tercapai dalam perjuangan antar kelompok. Akhirnya pengaruh atau jumlah menjadi penting selain kepemimpinan, akses terhadap pembuat kebijakan, kohesi internal dari kelompok, dan kekayaan. Teori ini disebut juga the hydrolic thesis, sebab mempersoalkan peranan kelompok penekan dan lobi-lobi antar kelompok yang ada untuk memutuskan satu hal. Masyarakat diasumsikan sebagai sebuah sistem dimana kelompok yang ada saling menekan dalam hukum aksi reaksi dalam merumuskan dan melaksanakan satu kebijakan publik. Secara teoritis, setiap kelompok tampak memiliki kekuatan yang sama, sehingga content dan context kebijakan itu masih netral. Tetapi sejalan dengan prinsip pareto optimum, ketika memaksimalkan kepentingan sebenarnya pada saat yang sama adalah meminimalkan kepentingan oranglain, maka sebenarnya ada kelompok yang lebih kuat dibanding kelompok yang lain, sehingga hakekat kebijakan publik bisa menjadi tidak netral lagi.

4. Rationalism: Kebijakan sebagai Effisent Goal Achievement. Nilai yang akan dicapai akan ditimbang dengan yang akan dikorbankan. Akan tetapi seorang pembuat kebijakan harus mengetahui preferensi nilai masyarakat, harus mengetahui alternatif-alternatif kebijakan yang ada, harus mengetahui konsekuensikonsekuensi atas setiap alternatif kebijakan, harus mengkalkulasikan rasio nilai yang dikorbankan dengan nilai-nilai sosial yang dicapai untuk tiap-tiap alternatif kebijakan sehingga seorang pembuat kebijakan harus memilih alternatif kebijakan yang efisien. Menurut teori ini, pilihan atas kebijakan merupakan hasil dari perhitungan tertentu, yang bisa saja tidak ada kaitannya dengan kebijaksanaan lain atau sebelumnya. Mungkin saja suatu kebijakan diambil pemerintah mengarah para suatu tujuan umum, dan masing-masing kebijakan bersifat komplementer 
terhadap yang lainnya.

5. Incrementalism: Kebijakan sebagai variasi di masa lalu. Model ini melihat sebuah kebijakan sebagai kelanjutan dari pencapaian tujuan kebijakan sebelumnya. Diimajinasikan bahwa ada suatu tujuan besar yang hendak dicapai. Kebijakan yang baru merupakan upaya untuk mencapai sasaran berikutnya, sambil melakukan penyesuaian dengan perkembangan lingkungan. Kebijakan hanya sekedar tambahan, bagian dari variasi dari masa lalu, dimana orang lebih senang melakukan model inkremental dalam kebijakan publik karena beberapa hal, yaitu:

a. Semua orang tidak memiliki banyak waktu, kecakapan dan cara untuk meneliti alternatif kebijakan yang ada.

b. Seorang pembuat kebijakan telah mendapat legitimasi dari pembuat kebijakan sebelumnya (di masa lalu).

c. Program terdahulu mungkin sudah memiliki investasi yang banyak.

d. Secara politic expedient sesuai selera publik.

e. Susah untuk mengetahui tujuan dan nilai-nilai sosial yang disetujui bersama.

6. Institutionalism: Kebijakan sebagai aktivitas institusional. Model ini memfokuskan diri pada apa yang seharusnya dilakukan oleh elemen yang ada dalam struktur birokrasi pemerintah, dengan cara melihat chart dari mekanisme kerja sesuai dengan aturan yang ada.

\section{Masalah Publik dan Masalah Kebijakan}

Permasalahan publik hingga konflik timbul dikarenakan masing-masing individu atau aktor memiliki kepentingan berbeda-beda. Kepentingan yang berbedabeda itu membuat pihak yang berkepentingan (stakeholders) bersuara dan ikut "menitipkan: suaranya tersebut. Proses tawar-menawar (bargaining) antar aktor pembuat kebijakan, dengan menggunakan kebebasan dan kewenangannya, seringkali disalahgunakan bukan untuk menyinkronkan kepentingan rakyat, melainkan untuk kekuasaan (power) itu sendiri. Banyaknya kepentingan yang masuk membuat aktor-aktor pembuat kebijakan sibuk dalam merumuskan kebijakan yang akan diterapkan (Taufiqurokhman, 2014).

Sejatinya, setiap kebijakan yang diputuskan merupakan hasil assessment dari masalah publik. Putra (2003) mengemukakan bahwa sebuah paradigma kebijakan publik yang kaku dan tidak responsif akan menghasilkan "wajah" negara yang kaku dan tidak responsif pula. Sebaliknya, paradigma kebijakan publik yang luwes dan responsif akan menghasilkan "wajah" negara yang luwes dan responsif pula.

Permasalahan kebijakan menjadi suatu hal yang sangat rumit layaknya sebuah benang yang telah kusut. Seidman, Seidman dan Abeysekere (dalam Taufiqurokhman, 2014) menyatakan bahwa suatu masalah dapat muncul akibat dari adanya beberapa hal yang ditesiskan tidak berjalan sebagaimana mestinya, yang mereka istilahkan dengan ROCCIPI, yaitu: 


\section{Rule (Peraturan).}

Peraturan dimaksudkan untuk mengatur segala perilaku manusia. Entah itu sebagai alih-alih (pembenaran) atau malah sebaliknya. Peraturan disini menyangkut semua masalah publik atau juga masalah yang ditimbulkan oleh publik. Masalah publik dapat muncul jika:

a. Rancunya atau membingungkannya bahasa yang digunakan dalam peraturan, seperti tidak dijelaskannya hal-hal yang dilarang dan yang harus dilakukan oleh masyarakat.

b. Beberapa peraturan malah berpeluang menyebabkan perilaku bermasalah.

c. Peraturan seringkali memperluas penyebagian-penyebagian perilaku bermasalah, bukan malah menghilangkannya.

d. Peraturan membuka peluang bagi perilaku yang tidak transparan.

e. Peraturan memberikan wewenang berlebih kepada pelaksana peraturan untuk bertindak represif.

2. Opportunity (Peluang).

Seorang individu akan dapat melakukan perilaku bermasalah jika kesempatan yang ada terbuka lebar. Artinya jika kesempatan terbuka, maka hal itu dapat mempengaruhi seorang individu untuk berperilaku menyimpang. Dalam hal ini, lingkungan menjadi faktor yang dominan menjadi penyebab perilaku menyimpang.

\section{Capacity (Kemampuan).}

Hal ini berkaitan dengan pertukaran yang disebabkan tidak dapat memerintah para individu untuk melakukan hal-hal di luar kemampuannya sehingga perlu adanya pemahaman mengenai kondisi-kondisi dari tiap individu.

\section{Communication (Komunikasi).}

Munculnya perilaku bermasalah dapat diakibatkan ketidaktahuan masyarakat tentang suatu peraturan. Ketidaktahuan tersebut dipicu oleh komunikasi yang tidak berjalan dengan baik (miss-communication). Permasalahan komunikasi sebenarnya merupakan permasalahan klasik di negeri yang kaya akan budaya dan sangat plural seperti Indonesia.

5. Interest (Kepentingan).

Adalah pandangan individu tentang akibat dan manfaat dari setiap perilaku. Akibat dan manfaat yang ditimbulkannya bisa dalam bentuk material (keuntungan ekonomi) dan juga non-material (pengakuan dan penghargaan).

6. Process (Proses).

Merupakan sebuah instrumen yang digunakan dalam menemukan penyebagian perilaku bermasalah yang dilakukan dalam atau oleh suatu organisasi. Beberapa proses yang digunakan untuk merumuskan masalah dalam organisasi antara lain 
proses pengumpulan input, proses pengolahan input menjadi keputusan, proses output dan proses umpan balik.

\section{Ideology (Nilai dan/atau Sikap).}

Adalah sekumpulan nilai yang dianut oleh suatu masyarakat untuk merasa, berpikir dan bertindak. Suatu nilai yang berlaku di dalam masyarakat biasanya merupakan hasil kesepakatan bersama dalam sebuah kelompok. Kemungkinan terjadinya konflik sangatlah besar mengingat nilai tersebut hidup dalam masyarakat yang plural dan heterogen (sebuah nilai yang dianut seringkali tidak sesuai dengan pandangan tiap kelompok).

Mencermati ketujuh hal tersebut di atas, maka ruang lingkup pandangan para aktor pembuat kebijakan atau para analis kebijakan dapat menjadi lebih sempit dan lebih sistematis dalam upaya menemukan langkah yang tepat untuk mengatasi masalah kebijakan. Namun Taufiqurokhman (2014) menyatakan hal tersebut hanya akan terwujud jika semua pihak yang terkait mengenai kebijakan, dapat meninggalkan egoisme masing-masing dalam rangka lebih mementingkan kepentingan bersama. Namun ketika ego kelompok yang lebih dominan, maka harapan itu hanyalah sebatas angan-angan belaka. Dalam kaitannya dengan konflik, Stoner dan Freeman (1994) pun menyatakan bahwa konflik organisasi mencakup ketidaksepakatan mengenai alokasi sumberdaya yang langka atau perselisihan mengenai tujuan, status, nilai, persepsi atau kepribadian. Maka hal-hal inilah yang merupakan penyebab munculnya konflik antar individu maupun antar kelompok di dalam organisasi sektor publik.

\section{Metode Penelitian}

Metode kajian ini adalah telaah literatur atau studi pustaka dan kajian beberapa hasil penelitian yang terkait dengan pengaruh nilai dalam eksistensi kebijakan publik. Teknik analisis data yang dipergunakan dalam penelitian ini adalah metode analisis konten yang menjelaskan dan menganalisis data dari hasil penelitian tentang bentukbentuk konflik di dalam lingkungan organisasi sektor publik, kemudian mengkaji cara mengelola konflik nilai yang terjadi di dalam perumusan kebijakan publik yang berkaitan dengan pengembangan organisasi yang telah ditelaah dari berbagai sumber tertulis, kemudian disajikan hasilnya.

\section{Hasil dan Pembahasan}

\section{Diagnosis Perbedaan Nilai sebagai Sumber Konflik di dalam Organisasi Sektor Publik}

Pada dasarnya, konflik selalu hadir pada setiap organisasi, baik organisasi kecil maupun besar, baik organisasi sektor privat maupun sektor publik (termasuk organisasi sosial dan organisasi pendidikan). Konflik juga dapat berdampak positif maupun negatif terhadap kinerja organisasi, tergantung pada sifat konflik dan pengelolaannya. Namun semakin besar organisasi, dan makin terspesialisasi 
kegiatannya, Eisenhardt dkk, (1997) dan Tang (2007) menyatakan bahwa semakin besar pula kemungkinan terjadinya konflik di dalam organisasi itu.

Dalam usaha mencapai tujuan organisasi, memang tidak jarang dapat terjadi adanya perbedaan persepsi atau cara pandang yang dilatarbelakangi oleh adanya perbedaan nilai yang dianut oleh individu atau kelompok di dalam organisasi. Perbedaan inilah yang kemudian menimbulkan adanya konflik. Sebagaimana dikemukakan oleh Stoner dan Wankel (dalam Wahyudi, 2008) bahwa konflik organisasi adalah ketidaksesuaian antara dua orang anggota organisasi atau lebih yang timbul karena fakta bahwa mereka harus berbagi dalam hal mendapatkan sumber-sumberdaya yang terbatas, atau aktivtas-aktivitas pekerjaan, dan atau karena fakta bahwa mereka memiliki status, tujuan, nilai-nilai atau persepsi yang berbeda.

Perbedaan nilai-nilai bagi setiap individu menciptakan perbedaan dalam merespon situasi. Hal ini dikemukakan oleh Dubrin (1984) bahwa a value refers to the important a person attaches to something. Dengan demikian, nilai merupakan panduan dan kepercayaan seseorang yang digunakan pada saat berhadapan dengan suatu situasi untuk melakukan pilihan. Perbedaan individu dalam hal nilai-nilai, keyakinan, kebutuhan dan kepribadian, persepsi ataupun pendapat, dikatakan oleh Wahyudi (2008) merupakan cakupan dari karakteristik individu, yang merupakan salah satu sumber konflik selain kondisi situasional dan struktur organisasi.

Robbins (1991), Feldman dan Arnold (1983) menyatakan bahwa konflik pada umumnya disebabkan kurangnya koordinasi kerja antar kelompok/departemen, dan lemahnya sistem kontrol organisasi. Permasalahan koordinasi kerja antar kelompok berkenaan dengan saling ketergantungan pekerjaan, keraguan dalam menjalankan tugas karena tidak terstruktur dalam rincian tugas, perbedaan orientasi tugas. Sedangkan kelemahan sistem kontrol organisasi yaitu kelemahan manajemen dalam merealisasikan sistem penilaian kinerja, kurang koordinasi antar unit atau bagian, aturan main yang tidak berjalan secara baik, serta terjadi persaingan yang tidak sehat dalam memperoleh penghargaan. Sebab-sebab dan alasan-alasan terjadinya konflik tersebut pada organisasi sektor publik kerapkali terjadi.

\section{Identifikasi Konflik yang Dihadapi Organisasi Sektor Publik terkait Pengalokasian Nilai dalam Kebijakan Pengelolaan Organisasi}

Tulisan ini berfokus pada kebijakan-kebijakan yang muncul di dalam organisasi sektor publik yang dilatarbelakangi oleh adanya perbedaan nilai dan kepentingan yang dianut oleh antar kelompok di dalam organisasi. Tidak hanya dalam lingkungan birokrasi yang pada realitanya tidak terlepas dari pengaruh berbagai kepentingan politik, lingkungan organisasi pendidikan juga dapat menghadapi konflik yang bersumber dari perbedaan nilai diantara anggota (individu maupun kelompok) organisasinya.

Hasil penelitian Sonhadji (1996) mengemukakan tentang dihadapkannya lembaga pendidikan pada pengelolaan yang memerlukan kualitas personil yang memadai terkait penempatan orang yang sesuai dengan kompetensi yang diperlukan untuk menghasilkan kinerja yang efektif dan efisien. Dalam identifikasi sumber 
konflik, maka temuan penelitian tersebut menunjukkan adanya perbedaan nilai atas analisis penempatan pegawai yang bisa jadi mengandung ketidaksamaan persepsi mengenai kompetensi yang diperlukan oleh suatu lembaga pendidikan dalam penyediaan sumberdaya manusia yang memiliki kinerja sesuai dengan visi dan misi organisasi. Lebih penting dari hal itu, kompetensi pemimpin lembaga pendidikan merupakan faktor sentral untuk mencapai keberhasilan, sebab pemimpin memegang peran dalam hal pengelolaan organisasi.

Hasil penelitian Nurtain (dalam Winardi, 2008) menghasilkan temuan bahwa perilaku kepemimpinan di dalam lembaga penyelenggara pendidikan yang tidak tepat pakai dan tidak tepat guna secara signifikan turut menjadi penyebab dari merosotnya mutu hasil belajar siswa / anak didik selain faktor kurangnya motivasi siswa, kurangnya perhatian orangtua dan kelemahan-kelemahan di pihak tenaga pengajar. Dalam identifikasi sumber konflik, maka tidak tepatnya perilaku kepemimpinan pada suatu organisasi publik bidang pendidikan, merupakan faktor individu yang memberi dampak kepada output organisasi. Siswa / anak didik sebagai output dari penyelenggaraan pendidikan mendapat imbas dari adanya penerapan nilai-nilai yang tidak tepat dari seorang pemimpin yang diwujudkan dalam perilaku kepemimpinannya, yang dapat saja berbeda dengan nilai-nilai yang dianut oleh anggota organisasinya (tenaga pengajar maupun siswa / anak didik).

Penelitian lainnya dilakukan oleh De Roche (dalam Winardi, 2008) menghasilkan kesimpulan kuatnya hubungan yang signifikan antara peran pemimpin lembaga pendidikan (sekolah) sebagai pemimpin dengan produktivitas dan prestasi tenaga pengajar juga siswa / anak didik. Sehingga manajemen menjadi faktor penting untuk mewujudkan tujuan pendidikan dimana lembaga pendidikan harus dikelola oleh administrator pendidikan yang profesional, dalam arti mampu mendayagunakan sumberdaya yang ada termasuk dapat mengelola konflik secara baik untuk meningkatkan kinerja anggota organisasi secara optimal dalam rangka meningkatkan produktivitas organisasi. Hasil penelitian tersebut secara jelas menggambarkan bahwa kesamaan pandangan terhadap nilai-nilai yang dianggap penting bagi kehidupan organisasi akan mampu membawa anggota organisasi pada pencapaian tujuan yang sama secara efektif.

Bagaimanapun, dalam lingkungan kebijakan pemegang otoritas (pimpinan organisasi) akan berupaya untuk mensukseskan perubahan kebijakan yang dilakukannya walaupun menghadapi kondisi konflik nilai. Ia akan menjadi pihak yang berada dalam posisi superordinasi akibat memiliki dominasi kekuasaan di dalam organisasi yang dipimpinnya. Sementara pihak lainnya yang memiliki landasan nilai-nilai dan kepentingan yang berbeda darinya, akan menjadi pihak yang berada dalam posisi subordinasi akibat memiliki kadar otoritas yang rendah atau bahkan tidak memegang otoritas. Superordinasi dan subordinasi inilah yang bisa saja dapat menimbulkan konflik yang semakin besar diantara para pihak. Sejalan dengan hal ini, Coser (1967) menyatakan tanpa ada jalan keluar yang meredakan konflik, hubungan-hubungan pertentangan antara pihak yang bertentangan akan semakin tajam. Jan Pen (dalam Winardi, 2006) menyatakan bahwa pihak penguasa atau pemegang otoritas harus memperlunak dan mengabsorbsi konflik-konflik. Coser 
(1967) lebih lanjut juga menyatakan bahwa perbedaan (yang tercipta dari kondisi konflik) merupakan peristiwa normal yang sebenarnya dapat memperkuat struktur sosial (dan/atau organisasi).

Lambert dkk (2006) menyatakan konflik merupakan situasi yang terjadi ketika ada perbedaan pendapat atau perbedaan cara pandang di antara beberapa orang, kelompok atau organisasi. Sikap saling mempertahankan diri, sekurang-kurangnya di antara dua kelompok, yang memiliki tujuan dan pandangan berbeda dalam mencapai suatu tujuan, maka mereka akan berada dalam posisi oposisi, bukan kerjasama. Apabila suatu organisasi dengan kaku menolak adanya perubahan, maka situasi konflik yang terjadi tidak akan reda. Tensi akan makin meningkat "suhunya" dan setiap konflik yang baru terjadi akan makin mencerai beraikan sub unit-sub unit organisasi yang bersangkutan. Jan Pen (dalam Winardi, 2006) menyatakan kelas-kelas kaku memang merupakan bagian dari sejarah umat manusia, tetapi perlu diingat bahwa meritokrasi yang arogan juga tidak lebih baik.

Maka pimpinan suatu organisasi harus memiliki kemampuan untuk melihat kejadian konflik dari segi fungsional dan disfungsional, sebab tidak mustahil kedua aspek tersebut muncul secara bersamaan yang oleh Robbins (1996) disebut sebagai the conflict paradox. Paradoks konflik memang seringkali trejadi pada organisasi yang berkembang dan mengalami percepatan penyesuaian terhadap kebutuhan masyarakat yang semakin maju. Adapun pencapaian tujuan dan performansi kerja organisasi dapat digunakan sebagai kriteria untuk menentukan apakah suatu konflik yang terjadi dalam organisasi bersifat fungsional atau disfungsional (Wahyudi, 2008).

Konflik fungsional adalah konfrontasi di antara individu atau kelompok yang menambah keuntungan kinerja organisasi, sedangkan konflik disfungsional adalah setiap perbedaan atau interaksi di antara individu atau kelompok yang menghalangi pencapaian tujuan organisasi (Gibson dkk, 1996). Segi fungsional konflik antara lain: 1) lebih mempersatukan anggota organisasi, 2) ditemukan cara perbaikan prestasi organisasi, 3) terciptanya iklim kerja yang kondusif, 4) alokasi dana yang lebih efisien, 5) penggantian pimpinan atau manajer yang lebih kreatif dan inovatif. Sedangkan aspek disfungsional konflik antara lain: 1) saat terciptanya kesulitan koordinasi dalam pencapaian tujuan, 2) kerjasama antar individu atau kelompok menjadi rusak, dan 3) performansi kerja rendah (Handoko, 1992).

\section{Relevansi Penanganan Konflik dalam Kebijakan Pengelolaan Organisasi}

Pengelolaan keragaman nilai dalam sebuah kebijakan publik sangat sulit untuk dilakukan. Bahkan sesungguhnya perubahan sosial maupun perubahan organisasi tidak terjadi melalui proses penyesuaian nilai-nilai yang dapat membawa perubahan. Namun terjadi akibat adanya konflik yang menghasilkan kompromi-kompromi yang berbeda dengan kondisi semula (Raho, 2007). Dengan kata lain, kondisi konflik bagaimanapun pada akhirnya akan mampu mencapai sebuah kesepakatan bersama.

Kasus perubahan kebijakan dalam organisasi sektor publik dapat dikaitkan dengan sejumlah hasil penelitian tentang konflik antar nilai dalam kebijakan publik. 
Penulis mengutip sebuah hasil penelitian tentang Good Governance yang berkaitan dengan pengelolaan nilai di dalam kebijakan publik, yaitu penelitian Graf, Huberts dan Smuders (2014) yang tiba pada kesimpulan bahwa Good Governance pada intinya berusaha menjawab tantangan dalam mengelola ketegangan yang muncul akibat berbagai nilai publik yang saling bertentangan. Mereka membedakan nilai-nilai good governance dalam tiga kategori besar, yakni performing governance (efisiensi dan efektivitas), proper governance (integritas, keadilan, kesetaraan dan kepatuhan pada hukum), dan responsive governance (partisipasi, transparansi, legitimasi dan akuntabilitas). Dalam keseharian pemerintah, terbukti terjadi benturan antara nilainilai tersebut. Misalnya antara efisiensi dengan pemerataan, antara transparansi dengan kepatuhan pada hukum, antara efektivitas dengan partisipasi, antara akuntabilitas dan efisiensi, dan seterusnya. Maka para pembuat keputusan tidak harus memilih nilai mana yang diutamakan pada isu dan konteks tertentu, tetapi mereka juga harus mengelola ketegangan yang muncul diantara nilai-nilai tersebut.

Namun, hasil penelitian tersebut tidak sejalan dengan hasil penelitian yang dilakukan oleh Premfors (dalam Taufiqurokhman, 2016); Le Grand (2007) yang menyatakan bahwa trade-off antar nilai atau prinsip menjadi bagian yang tidak terhindarkan dari proses kebijakan publik. Beberapa hasil penelitian ini tiba pada kesimpulan bahwa seringkali para pembuat kebijakan membuat pertukaran (trade-off) saat menghadapi konflik antar nilai, membuat tingkatan prioritas nilai dan hal itu berlaku tidak hanya bagi penerima manfaat atau pihak-pihak yang terkena dampak dari suatu kebijakan, tetapi juga bagi mereka sendiri selaku pembuat kebijakan. Witesman dan Walters (2014) menyatakan bahwa tingkatan prioritas nilai itu bergerak dari satu waktu dan konteks ke waktu dan konteks lainnya.

Konflik dikatakan oleh Coser (1967) sebagai proses yang bersifat instrumental dalam pembentukan, penyatuan dan pemeliharaan struktur sosial/organisasi. Hasil pengamatan Simmel (dalam Coser, 1967) menyatakan bahwa peningkatan konflik kelompok dapat dihubungkan dengan peningkatan interaksi dengan masyarakat secara keseluruhan atau seluruh anggota organisasi. Justru bila konflik dalam kelompok tidak ada, berarti integrasi kelompok tersebut dengan masyarakat lemah. Dalam struktur besar atau kecil, konflik in-group merupakan indikator adanya suatu hubungan yang sehat.

Harsey dan Blanchard (1986) menyatakan bahwa kemampuan pemimpin organisasi dalam menanggulangi konflik dapat berpengaruh pada produktivitas kerja organisasi. Dikemukakan pula oleh Cummings (dalam Wahyudi, 2008) bahwa penyelesaian konflik secara adil dan jujur yang dilakukan oleh pimpinan organisasi akan meningkatkan semangat kerja dan produktivitas anggota organisasi. Maka pimpinan organisasi harus bertanggungjawab terhadap pengelolaan konflik di dalam organisasi. Tugas pimpinan adalah mengarahkan dan mengelola konflik agar bernilai fungsional bagi organisasi.

Walaupun peristiwa konflik menurut pandangan kontemporer berfungsi positif, namun pandangan ini selalu mewaspadai kemungkinan timbulnya dampak negatif yang bersumber dari konflik yang terlalu tinggi dan tidak terkendali. Pandangan kontemporer menyadari bahwa tidak semua konflik bersifat fungsional dan 
berkeyakinan terdapat konflik yang dapat menimbulkan pengaruh negatif bagi kelangsungan organisasi. Wahyudi (2008) menyatakan bahwa pimpinan organisasi yang bersikap positif terhadap konflik akan lebih banyak berperan dalam mengelola konflik dibandingkan dengan pimpinan yang bersikap negatif (tradisional).

Untuk menjaga agar suatu organisasi publik dapat memiliki kinerja individu dan kinerja kelompok yang efektif dan efisien dalam situasi adanya konflik, diperlukan suatu pemahaman terhadap dimensi-dimensi orientasi penanganan konflik sebagaimana yang dikemukakan oleh Thomas (dalam Dunnette, 1976).

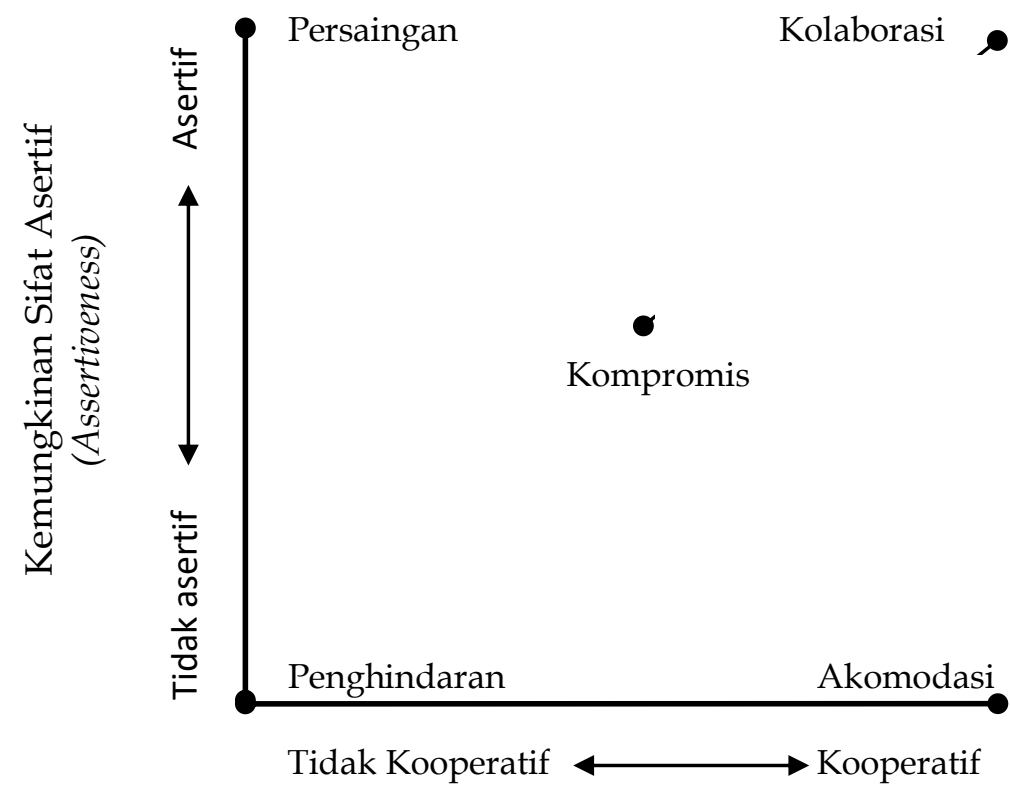

Kemungkinan Kerjasama

(Cooperativeness)

Gambar 1. Dimensi-dimensi Orientasi Penanganan Konflik

Terdapat lima macam orientasi penanganan konflik yakni: 1) Persaingan (competition) sebagai bentuk sifat asertif dan tidak kooperatif, 2) Kolaborasi (collaboration) sebagai bentuk sifat asertif dan kooperatif, 3) Penghindaran (avoidance) sebagai bentuk sifat tidak asertif dan tidak kooperatif, 4) Akomodasi (accommodation) sebagai bentuk sifat tidak asertif dan kooperatif, serta 5) Kompromis (compromise) sebagai bentuk antara sifat asertif dan kooperatif. Dimensi kooperatif dimaknai sebagai dimensi hingga dimana satu pihak berupaya untuk memenuhi kepentingankepentingan pihak lain), sedangkan dimensi assertiveness dimaknai sebagai dimensi hingga dimana satu pihak berupaya memenuhi kepentingan dirinya sendiri.

Adapun kondisi atau situasi yang tepat untuk memanfaatkan lima macam orientasi penanganan konflik tersebut tampak pada tabel 1. 
Tabel 1. Kondisi atau Situasi Tepat untuk Memanfaatkan Dimensi Orientasi Penanganan Konflik.

\begin{tabular}{|c|c|c|c|}
\hline No. & $\begin{array}{l}\text { Orientasi } \\
\text { Penanganan } \\
\text { Konflik } \\
\end{array}$ & Penjabaran & Kondisi atau Situasi yang Tepat \\
\hline 1 & $\begin{array}{l}\text { Persaingan } \\
\text { (competition) }\end{array}$ & $\begin{array}{l}\text { Upaya-upaya yang diatur oleh } \\
\text { peraturan guna mencapai suatu } \\
\text { tujuan tanpa memperhatikan } \\
\text { dampaknya terhadap pihak lain. }\end{array}$ & $\begin{array}{l}\text { 1. Apabila tindakan desisif cepat bersifat vital. } \\
\text { 2. Terhadap persoalan-persoalan penting, } \\
\text { dimana tindakan-tindakan tidak populer } \\
\text { perlu diterapkan. } \\
\text { 3. Terhadap persoalan-persoalan yang vital } \\
\text { bagi kesejahteraan organisasi yang } \\
\text { bersangkutan, dan apabila kita mengetahui } \\
\text { bahwa kita benar. } \\
\text { 4. Terhadap orang-orang yang mengambil } \\
\text { kesempatan terhadap perilaku non } \\
\text { kompetitif. }\end{array}$ \\
\hline 2 & $\begin{array}{l}\text { Kolaborasi } \\
\text { (collaboration) }\end{array}$ & $\begin{array}{l}\text { Sebuah situasi dimana pihak- } \\
\text { pihak yang terlibat dalam suatu } \\
\text { konflik, masing-masing } \\
\text { berkeinginan untuk memuaskan } \\
\text { kepentingan semua pihak. }\end{array}$ & $\begin{array}{l}\text { 1. Untuk mencapai sebuah pemecahan } \\
\text { integratif, apabila kedua macam } \\
\text { kepentingan dianggap terlampau penting } \\
\text { untuk dikompromi. } \\
\text { 2. Apabila sasaran kita adalah untuk belajar. } \\
\text { 3. Untuk mempersatukan pemahaman orang- } \\
\text { orang yang memiliki perspektif yang } \\
\text { berbeda-beda. } \\
\text { 4. Untuk mencapai suatu komitmen dengan } \\
\text { jalan melebur kepentingan-kepentingan } \\
\text { dalam wujud suatu konsensus. } \\
\text { 5. Untuk mengatasi perasaan-perasaan yang } \\
\text { telah mempengaruhi suatu hubungan. }\end{array}$ \\
\hline 3 & $\begin{array}{l}\text { Penghindaran } \\
\text { (avoidance) }\end{array}$ & $\begin{array}{l}\text { Upaya untuk menarik diri dari } \\
\text { suatu konflik, atau upaya untuk } \\
\text { meredam suatu konflik. }\end{array}$ & $\begin{array}{l}\text { 1. Apabila persoalan tertentu kurang, artinya } \\
\text { atau sewaktu persoalan-persoalan lebih } \\
\text { penting perlu dihadapi. } \\
\text { 2. Apabila kita merasa tidak adanya } \\
\text { kemungkinan untuk memenuhi } \\
\text { kepentingan-kepentingan kita. } \\
\text { 3. Apabila kekacauan potensial melebihi } \\
\text { manfaat dari suatu pemecahan. } \\
\text { 4. Untuk menyuruh orang-orang menjadi } \\
\text { tenang dan mencapai kembali perspektif. } \\
\text { 5. Apabila tindakan mengumpulkan } \\
\text { informasi dianggap lebih penting } \\
\text { dibandingkan pengambilan keputusan } \\
\text { segera. A } \\
\text { 6. Apabila pihak lain dapat menyelesaikan } \\
\text { konflik yang ada secara lebih efektif. } \\
\text { 7. Apabila isu-isu yang ada berkaitan atau } \\
\text { bersifat simtomatik bagi isu-isu lain. }\end{array}$ \\
\hline 4 & $\begin{array}{l}\text { Akomodasi } \\
\text { (accommodation) }\end{array}$ & $\begin{array}{l}\text { Kesediaan pihak tertentu di dalam } \\
\text { sebuah konflik untuk lebih } \\
\text { mementingkan kepentingan pihak } \\
\text { oponen, dibandingkan dengan } \\
\text { kepentingannya sendiri. }\end{array}$ & $\begin{array}{l}\text { 1. Apabila ternyata bahwa kita salah (keliru)- } \\
\text { atau untuk memungkinkan didengarnya } \\
\text { saran lebih baik, untuk belajar dan untuk } \\
\text { menunjukkan bahwa kita cukup terbuka } \\
\text { untuk menerima pendapat-pendapat lain. } \\
\text { 2. Apabila isu-isu lebih penting bagi pihak } \\
\text { lain daripada untuk kita sendiri, guna } \\
\text { memuaskan pihak lain dan untuk } \\
\text { mempertahankan kerjasama dengan pihak } \\
\text { lain. } \\
\text { 3. Untuk membentuk kredit-kredit sosial } \\
\text { untuk isu-isu masa mendatang. }\end{array}$ \\
\hline
\end{tabular}




\begin{tabular}{|c|c|c|c|}
\hline & & & $\begin{array}{l}\text { 4. Untuk meminimasi kerugian apabila kita } \\
\text { terdesak dan kalah. } \\
\text { 5. Apabila kondisi harmoni dan stabilitas } \\
\text { dianggap sangat penting. } \\
\text { 6. Untuk memungkinkan para bawahan } \\
\text { belajar dari kesalahan-kesalahan mereka. }\end{array}$ \\
\hline 5 & $\begin{array}{l}\text { Kompromis } \\
\text { (compromise) }\end{array}$ & $\begin{array}{l}\text { Situasi dimana masing-masing } \\
\text { pihak di dalam suatu konflik, } \\
\text { mengorbankan suatu hal. }\end{array}$ & $\begin{array}{l}\text { 1. Apabila tujuan-tujuan memang penting, } \\
\text { tetapi tidak sebanding dengan upaya untuk } \\
\text { mencapainya. } \\
\text { 2. Apabila para oponen dengan kekuatan } \\
\text { yang sebanding terikat pada tujuan-tujuan } \\
\text { yang saling menguntungkan. } \\
\text { 3. Untuk mencapai penyelesaian sementara } \\
\text { bagi isu-isu yang kompleks. } \\
\text { 4. Untuk mencapai pemecahan-pemecahan } \\
\text { cepat karena desakan waktu. } \\
\text { 5. Digunakan sebagai suatu landasan apabila } \\
\text { kolaborasi atau persaingan tidak berhasil. }\end{array}$ \\
\hline
\end{tabular}

Sumber: Diolah dari Thomas, 1977 (dalam Winardi, 2006).

Maka seorang pemimpin suatu organisasi harus mampu mengidentifikasi dimensi orientasi penanganan konflik dan menyadari kondisi atau situasi yang tepat untuk melakukannya sebagaimana uraian pada tabel 1. Sebab pemahaman dan pengambilan keputusan mengenai langkah penanganan konflik yang tepat akan mampu membawa organisasi pada pemanfaatan konflik yang fungsional bagi perkembangan organisasi.

Dalam menghadapi situasi konflik, terdapat beberapa hal yang sebaiknya dapat dihandari oleh seorang pemimpin organisasi. Jan Pen (dalam Winardi, 2006) mengemukakan hal-hal pokok yang harus dihindari dari permasalahan konflik yang berpengaruh terhadap harmonisasi organisasi sebagai berikut: 1) Pertentangan kepentingan di dalam organisasi tidak boleh menyebabkan adanya kelompokkelompok yang terisolasi. Hal tersebut akan menyebabkan timbulnya perasaan dendam dan keterasingan. Meritokrasi yang arogan bukan hal yang baik bagi organisasi, 2) Konflik-konflik yang muncul tidak boleh mencapai wujud pertentangan antara blok-blok yang tertutup, dimana senantiasa orang-orang yang itu-itu juga berhadapan satu sama lain, dan pihak yang sama senantiasa mengalami kekalahan. Hal itu akan menyebabkan timbulnya kekakuan dan tercerai-berainya organisasi, 3) Pembagian pendapatan pun tidak boleh terlampau tidak merata dan karena dapat menimbulkan keputusasaan. Apabila demikian halnya, maka konflik-konflik yang ada akan semakin kuat, dan timbul kondisi-kondisi sosial psikologi yang merugikan anggota organisasi.

\section{Kesimpulan}

Realitas menunjukkan bahwa konflik selalu hadir dalam setiap organisasi dan keberadaannya tidak dapat dihindarkan. Konflik dan perubahan merupakan dua hal yang saling berkaitan satu sama lain. Konflik dapat menimbulkan perubahan, tetapi sebaliknya pun perubahan dapat pula menimbulkan berbagai konflik. Terlepas dari ada tidaknya konflik, konflik sesungguhnya merupakan masalah persepsi, sebab 
konflik perlu dipersepsi oleh pihak-pihak yang terlibat di dalamnya sehingga keberadaannya akan ditentukan oleh persepsi yang terbentuk.

Persepsi seseorang terhadap konflik dilatarbelakangi oleh pengalaman dalam mengelola organisasi, tingkat pendidikan, kepercayaan terhadap nilai, juga pengaruh lingkungan sosial. Konflik terjadi dikarenakan ada kondisi yang mengawalinya dan kondisi itu merupakan sumber munculnya konflik. Munculnya berbagai konflik merupakan dinamika dalam perkembangan organisasi. Oleh karena itu pimpinan organisasi perlu memahami sumber-sumber konflik dan mengelola konflik agar bernilai fungsional guna memanfaatkannya untuk meningkatkan performansi organisasi melalui kesuksesan kebijakan pengembangan organisasi yang ia buat.

Pimpinan organisasi yang bersikap positif terhadap konflik akan lebih banyak berperan dalam mengelola konflik dibandingkan dengan pimpinan yang bersikap negatif (tradisional). Konflik yang tidak dikendalikan secara efektif pada akhirnya akan menimbulkan pengaruh yang buruk pada kinerja organisasi. Namun bila pimpinan organisasi mempunyai kemampuan mengendalikan konflik yang baik, maka organisasi akan mendapatkan keuntungan dalam pengembangannya.

\section{Daftar Pustaka}

Bromell, David. (2012). Evidence, Values and Public Policy. ANZSOG Occasional Paper. Coser, Lewis (ed). (1965). The Function of Social Conflict. Free Press. New York.

Coser, Lewis. (1967). Continuities in the Study of Social Conflict. Free Press. New York. de Graaf, Gjalt, Leo Huberts dan Remco Smulders. (2014). “Coping with Public Value Conflicts". Administration and Society: pp 1-27.

de Graaf, Gjalt dan Zeger van der Wal. (2010). “Managing Conflicting Public Values: Governing with Integrity and Effectiveness". American Review of Public Administration, 40 (6): pp 623-630.

Dubrin, A.J. (1984). Foundations of Organizational Behavior: An Applied Perspective. Prentice-Hall International Inc. London.

Dunnette, M. (ed). (1976). Handbook of Industrial and Organizational Psychology. Rand McNelly.

Dye, Thomas R. (1992). Understanding Public Policy. Prentice-Hall, Inc. Englewood Cliffs. New Jersey. USA.

Eisenhardt, K.M., Jean L.K., Bourgeois III L.J. (1997). “Conflict and Strategic Choice: How Top Management Team Disagree”. California Management Review, 39 (2).

Feldman, D.C. dan Arnold, H.J. (1983). Managing Individual and Group Behavior in Organizations. McGraw-Hill International Book Company. London.

Gibson, J.L., Ivancevich, J.M. dan Donnelly, Jr., J.H. (1996). Organisasi: Perilaku, Struktur dan Proses. Edisi Ke Delapan. Alih Bahasa: Nunuk Ardiani. Binarupa Aksara. Jakarta. 
Handoko, T. Hani. (1992). Manajemen. Edisi Kedua. Badan Penerbit Fakultas Ekonomi. Yogyakarta.

Nugroho, Riant. (2018). Public Policy. Edisi Keenam, Revisi, Cetakan Kedua. Elex Media Kompetindo. Jakarta.

O'Kelly, C dan M.J. Dubnick. (2005). “Taking Tough Choices Seriously: Public Administration and Individual Moral Agency". Journal of Public Administration Research and Theory, 16 : pp 393-415.

Poloma, Margaret M. (1994). Sosiologi Kontemporer. PT Raja Grafindo Persada. Jakarta.

Putra, Fadillah. (2003). Paradigma Kritis dalam Studi Kebijakan Publik. Pustaka Pelajar. Yogyakarta.

Raho, Bernard. (2007). Teori Sosiologi Modern. Prestasi Pustaka Publisher. Jakarta.

Robbins, Stephen P. (1991). Organizational Behavior. Prentice Hall. Englewood Cliffs. New Jersey.

Sonhadji, A.K.H. (1996). Profesionalisme dalam Pengelolaan Pendidikan. Makalah disajikan pada Konvensi Nasional Pendidikan Indonesia III di Ujungpandang, 4-7 Maret 1996.

Spicer, M.W. (2009). Value Conflict and Legal Reasoning in Public Administration. Administrative Theory \& Praxis, 314: pp 537-555.

Stoner, J.A.F. dan Freeman, R.E. (1994). Management. Fifth Edition. Prentice-Hall A Division of Simon \& Schuster, Inc. Englewood Cliffs, New Jersey.

Subarsono, Agustinus (ed). (2016). Kebijakan Publik dan Pemerintahan Kolaboratif, Isu-isu Kontemporer. Gava Media. Yogyakarta.

Tang, H.C. (2007). “A Study of the Relationship of the Perception of Organizational Promises Among Faculty and Staff Members in the Technical and Vocational Colleges". The Journal of American Academy of Business, Cambridge, 12 (1).

Taufiqurokhman. (2014). Kebijakan Publik, Pendelagian Tanggungjawab Negara kepada Presiden selaku Penyelenggara Pemerintahan. Cetakan Pertama. Fisip Universitas Moestopo Beragama Pers. Jakarta.

Wahyudi. (2008). Manajemen Konflik dalam Organisasi: Pedoman Praktis bagi Pemimpin. Cetakan Ketiga. Alfabeta. Bandung.

Winardi. (2006). Manajemen Perubahan. Cetakan Kedua. Kencana Prenada Media Group. Jakarta. 